\title{
GLACIFLUVIÁLNÍ VÝPLAVOVÁ PLOŠINA U KOLNOVIC A JEJÍ SROVNÁNÍ S TERMINOGLACIÁLNÍMI KUŽELY MEZI SOKOLSKÝM HŘBETEM A ZLATOHORSKOU VRCHOVINOU U JESENÍKU
} \author{
Ridge and Zlaté Hory Highlands near the Jeseník town \\ Martin Hanáček \\ Oddělení prírodních věd, Slezské zemské muzeum, 74601 Opava \\ Ústav geologických věd, PřF MU, Kotlářská 2, 61137 Brno; e-mail: HanacekM@seznam.cz
}

Glaciofluvial outwash plain at Kolnovice compared with terminoglacial fans between Sokol

(14-22 Jeseník)

Key words: Czech Silesia, outwash-plain deposits, terminoglacial fan deposits, Pleistocene, continental glaciation

\begin{abstract}
Glaciofluvial sediments at Kolnovice originated on an outwash plain running along the ice sheet front. Its material is variable from petrographical and provenance point of view, as it was deposited from various parts of a wide ice sheet front. This contrasts with petrologically monotonous deposits of terminoglacial fans in this area (Písečná and Javorná sites), which originate from one marginal lobe of the ice sheet. In addition, the material in terminoglacial fans comes from the direct surroundings of the sites having been transported only a short distance.
\end{abstract}

\section{Úvod}

V prostoru mezi Zlatohorskou vrchovinou a Sokolským hřbetem ssv. od Jeseníku pokrývají velkou plochu ledovcové sedimenty, především glacifluviální písky a štěrky. Území leží v okrajové zóně pleistocenního kontinentálního zalednění (obr. 1). Pravděpodobně již od terciéru tudy protéká řeka Bělá (Cháb et al. 2004), jejíž geomorfologická aktivita zčásti predisponovala styl glacifluviální sedimentace i složení klastického materiálu. Podle dosavadních výzkumů (Gába 1981, Cháb et al. 2004, Žáček et al. 2004) vznikaly zdejší glacifluviální uloženiny v subglaciálním a terminoglaciálním až proglaciálním prostředí. Zatím nejpodrobněji byla $\mathrm{v}$ této oblasti zpracována lokalita Písečná (Gába 1981). Předložený příspěvek se zaměřuje na dnes intenzivně těženou pískovnu na okraji Kolnovic, $\sim 1,5 \mathrm{~km}$ ssz. od Mikulovic, a na její srovnání s dalšími dvěma akumulacemi vyvíjejícími se před čelem ledovce (Písečná, Javorná). Ledovcové sedimenty u Kolnovic a Písečné spadají do mladšího elsterského zalednění (Cháb et al. 2004, Žáček et al. 2004, Nývlt et al. 2011) u lokality Javorná pocházejí ze staršího elsterského zalednění (Cháb et al. 2004, Nývlt et al. 2011). a Nývlta et al. (2011).

\section{Metodika}

V kolnovické pískovně byla popsána sukcese glacifluviálních uloženin. Vyčlenění, kódování a interpretace litofacií vycházejí z práce Zielińského - Van Loona (2003). Podle vztahu litofacií byly vyčleněny litofaciální asociace. Vzorky pro valounové analýzy byly odebrány ze začištěných profilů pomocí lopatky a normalizovaného síta. Studium se zaměřilo na frakci $16-64 \mathrm{~mm}$ v b-ose

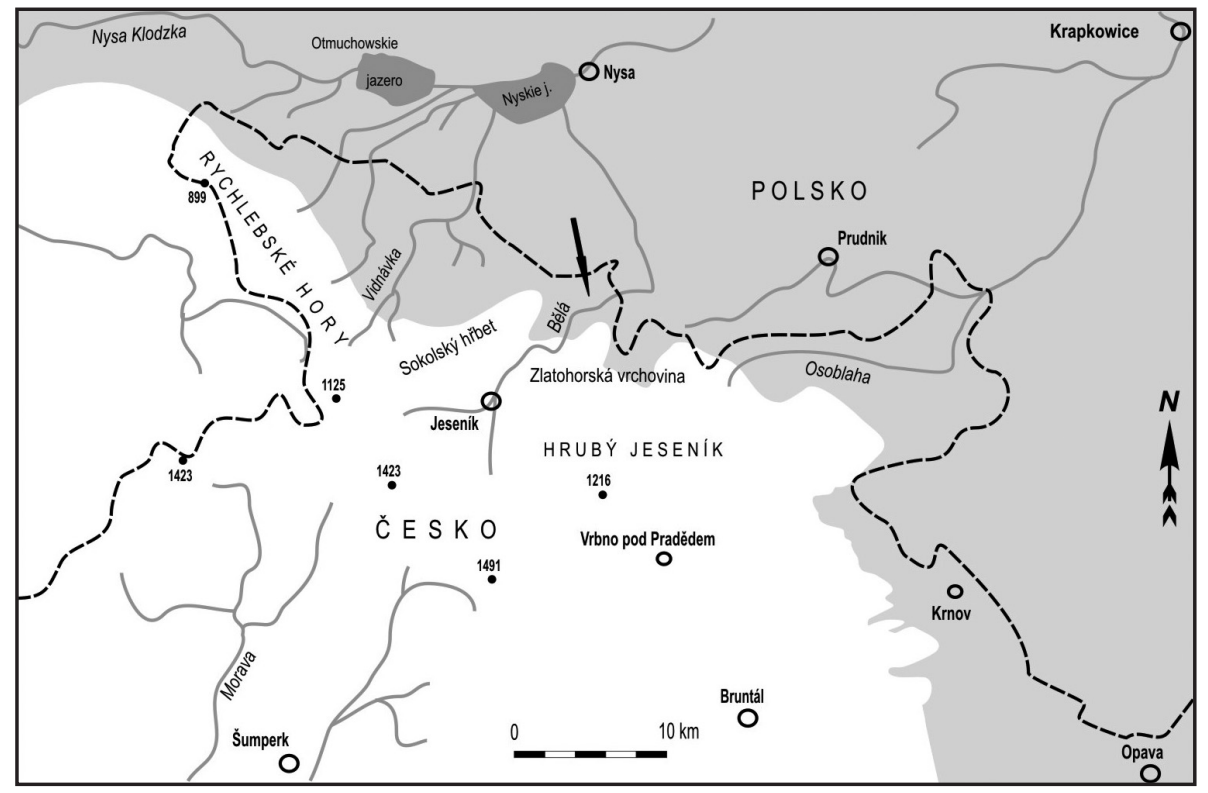

Obr. 1: Kontinentální zalednění severního předpolí Rychlebských hor, Hrubého Jeseníku a sz. části Nízkého Jeseníku. Šipka: studovaná oblast. Šedě: maximální rozsah kontinentálního ledovce v mladším elsterském zalednění. Bíle: nezaledněná oblast. Upraveno podle Sikorové et al. (2006)

Fig. 1: Continental glaciation of the northern foreland of the Rychlebské hory Mts., Hrubý Jeseník Mts. and the northwestern part of the Nízký Jeseník Mts. Arrow: studied area. Grey: maximum extent of continental glacier during Elsterian II glaciation. White: non glaciated area. Adopted from Sikorová et al. (2006) and Nývlt et al. (2011). 


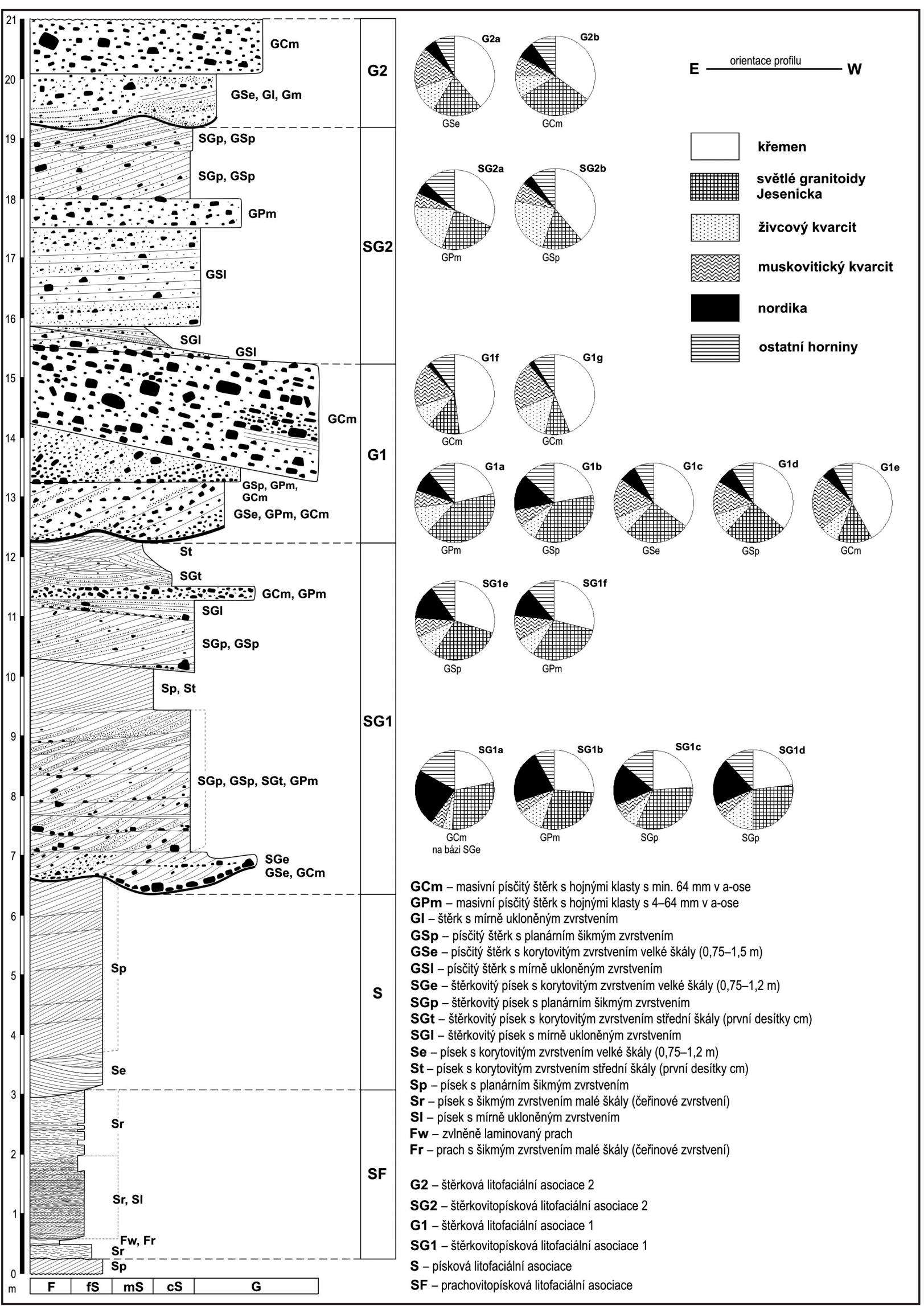

Obr. 2: Profil glacifluviálními sedimenty u Kolnovic, jižní stěna pískovny. Svislá pozice grafů valounových analýz odpovídá pozici odebraných vzorků v profilu.

Fig. 2: Composite lithofacies log through the southern wall of the Kolnovice sandpit. The vertical position of clast petrology diagrams corresponds to sample position in the section. 
a pouze orientačně na frakci $64-256 \mathrm{~mm}$ v b-ose u akumulace nejhrubšího sedimentu na lokalitě. Valouny byly zkoumány makroskopicky a jen výjimečně ve výbrusech. Determinace hornin vychází z geologických map a jejich vysvětlivek v zájmové oblasti (Svoboda et al. 1961, Pouba et al. 1962, Žáček 1995, Cháb et al. 2004, Žáček et al. 2004) a dále z práce Gáby - Peka (1999).

\section{Litofaciální vývoj sedimentů}

V pískovně jsou odkryty glacifluviální sedimenty o mocnosti přes $20 \mathrm{~m}$ (obr. 2). Jedná se o písky, štěrkovité písky a písčité štěrky, převážně s šikmým zvrstvením. V některých polohách se vyskytují různě mocné masivní písčité štěrky. Tenké polohy prachu jsou velmi ojedinělé a vázané na dolní část odkryvu. Ve spodních $\sim 15 \mathrm{~m}$ mocnosti představují sedimenty postupně nahoru hrubnoucí sekvenci. Poté následuje další, i když ne tolik zřetelný cyklus. Na úrovni $\sim 6 .-7 . \mathrm{m}, \sim 12$. m a $\sim 19$. m se nacházejí výrazné erozní báze. Podle zrnitosti a zvrstvení byly definovány jednotlivé litofacie a na základě jejich vzájemných vztahů bylo vyčleněno šest litofaciálních asociací.

Prachovitopísková litofaciální asociace (SF) je tvořena především několik desítek $m$ laterálně stálým tělesem jemnozrnných prachovitých čeřinově zvrstvených písků (Sr). Celá akumulace sestává $\mathrm{z}$ několika dílčích jednotek $s$ různou orientací čeřin. Uvnitř tělesa se objevují polohy zvlněně laminovaného prachu $(\mathrm{Fw})$, který přechází do prachovitého čeřinově zvrstveného písku. Tyto polohy jsou max. $10 \mathrm{~cm}$ mocné a $\sim 9-10 \mathrm{~m}$ široké.

Pískovou litofaciální asociaci (S) představují šedé jemnozrnné písky. Na bázi asociace se korytovitě zahlubují do podložních sedimentů (Se), výše se jedná o naložené sety se subhorizontálními bázemi a šikmým planárním zvrstvením (Sp). Stejné písky byly zastiženy i v podloží asociace SF, která proto může být součástí mnohem mocnější asociace S. Písková asociace je vyvinuta jen ve v. části pískovny, jelikož uprostřed odkryvu nasedá na asociaci SF prímo asociace SG1.

Spodní štěrkovitopísková litofaciální asociace (SG1) představuje nejpestřejší sedimenty celé sukcese. Bazální výmoly (šiřka přes $6 \mathrm{~m}$, mocnost výplně $\sim 1 \mathrm{~m}$ ) vyplňují písčité štěrky až štěrkovité písky (SGe, GSe) a místy leží prímo na bázi tenká štěrková poloha s klasty $\sim 10-20 \mathrm{~cm}$ velkými $(\mathrm{GCm})$. Celkově převažují štěrkovité písky, tvořící na sebe naložené ploché sety mocné $\sim 0,3-0,7 \mathrm{~m}$ a laterálně stálé až $10 \mathrm{~m}$. Zvrstvení v těchto setech je šikmé planární nebo korytovité, báze jsou rovné nebo mírně zahloubené. Typické je rytmické střídání vrstev písku, štěrčíku až štěrku a dále rozptýlené klasty až do $15 \mathrm{~cm}$ velikosti. Nápadná je hojnost obrněných závalků velkých až $25 \mathrm{~cm}$, které tvoří tyto sedimenty: prachovitopískový diamikton ( 1\% klastů do $2 \mathrm{~cm}$ ), velmi jemnozrnný laminovaný prachovitý písek až prach a masivní písčitý prach. Podřízeně se objevují ploché tenké polohy masivních písčitých štěrků (GCm, GPm). Štěrkovité písky se střídají s jednotlivými sety nebo se soubory setů jemno- až hrubozrnných korytovitě i šikmo planárně zvrstvených písků (St, Sp). Tyto tvoří v jv. části těžebny $\sim 4 \mathrm{~m}$ mocnou akumulaci, laterálně zcela nahrazující štěrkovitopískové facie. Rovněž v nejsvrchnější části asociace dominují písková tělesa s šířkami korytových setů mezi desetinami $\mathrm{m}$ a $\sim 7 \mathrm{~m}$ a s mocnostmi v prvních desítkách cm. Sedimenty asociace SG1 jsou ve spodní části dobře vytříděné, téměř bez prachové příměsi. Ve svrchní části je vytřídění horší.

Spodní štěrková litofaciální asociace (G1) nastupuje výraznou erozní bází, jejíž minimální laterální rozsah činí $\sim 100 \mathrm{~m}$ a značně tak přesahuje velikost sedimentárních těles. Sedimenty nad bází jsou mnohem hưře vytř́iěné než $\mathrm{v}$ podloží báze. $\mathrm{V}$ místech, kde je báze jen slabě zvlněna, leží v jejím nadloží polohy masivních písčitých štěrků a v malých výmolech jsou nahromaděny klasty velké až $50 \mathrm{~cm}$. Většinou má báze podobu velkých korytových výmolů, širokých 4-15 m a vyplněných korytovitě zvrstvenými písčitými štěrky mocnými 1,25-2,00 m (GSe). Zvrstvení má formu střídání štěrků s podpůrnou strukturou klastů (valouny $\sim 5-10 \mathrm{~cm}$ ) a vrstev štěrkovitých písků s podpůrnou strukturou mezihmoty. $V$ jejich nadloží byly uloženy šikmo planárně zvrstvené písčité štěrky (GSp) a masivní písčité štěrky (GPm, GCm) s četnými klasty o velikosti $\sim 5-15 \mathrm{~cm}$. Následují masivní štěrky s hojnými klasty o velikosti $\sim 10-20 \mathrm{~cm}$, vzácně až $40 \mathrm{~cm}$, a s převahou podpůrné struktury štěrkovitopískové mezihmoty (GCm). Tyto štěrky tvoří max. $2,5 \mathrm{~m}$ mocné ploché těleso $\mathrm{s}$ rovnou bází ukloněnou k SSZ. Laterální rozsah se pohybuje $\mathrm{v}$ desítkách $\mathrm{m}$.

Svrchní štěrkovitopísková litofaciální asociace (SG2) se od SG1 odlišuje četnějším výskytem rozptýlených klastů do $20 \mathrm{~cm}$ velikosti a laterálními i vertikálními přechody mezi štěrkovitými písky a písčitými štěrky (SGp, GSp). Oproti SG1 je také mnohem hưře vytříděná, obsahuje vyšší prríměs jemnozrnného písku a prachu.

Svrchní štěrková litofaciální asociace (G2) začíná podobně jako G1 výraznou erozní bází přesahující rozsah podložních i nadložních těles. Od G1 se liší menší šiŕkou a zahloubením korytových těles (šírka: $2-7 \mathrm{~m}$, zahloubení: $0,25-0,75 \mathrm{~m}$ ) a menší hrubozrnností. Největší výmol vyplňují korytovitě zvrstvené písčité štěrky (GSe), nad nimi a v dalších výmolech jsou pak masivní písčité štěrky $(\mathrm{GPm})$ a mírně ukloněně zvrstvené štěrky $(\mathrm{Gl}) \mathrm{s}$ podpůrnou strukturou mezihmoty i klastů. Celou sedimentární sekvenci uzavírají masivní písčité štěrky s hojnými klasty velkými 10-20 cm (GCm), které zde nejsou tak početné jako ve stejné facii u asociace G1.

\section{Materiál štěrkových klastů}

Nejčastější klasty jsou tvořeny křemenem, světlými (bělošedými) granitoidy z jesenického krystalinika, muskovitickým kvarcitem, živcovým kvarcitem a nordickými horninami. Pestrá škála ostatních hornin je přítomna jen v desetinách \% nebo v prvních \% (obr. 2, tab. 1).

Křemen má převážně světle šedou, méně často bílou, tmavě šedou a nahnědlou barvu. Zhruba polovinu klastů tvoří křemen s drobnými agregáty nebo krystaly dalších minerálů (především bílých živců a slíd, ojediněle andaluzitu, amfibolu, sillimanitu, granátu) nebo se zbytky hornin (fylitu, světlých granitoidů, kvarcitů, svoru, ruly). Poměr podílů čistě křemenných klastů a klastů křemene se zbytky hornin a dalších minerálů je proměnlivý a nezávislý 


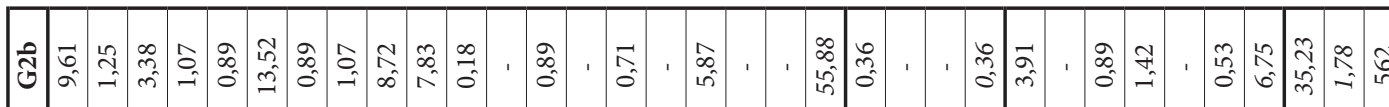

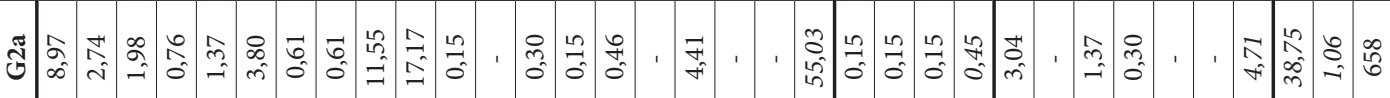

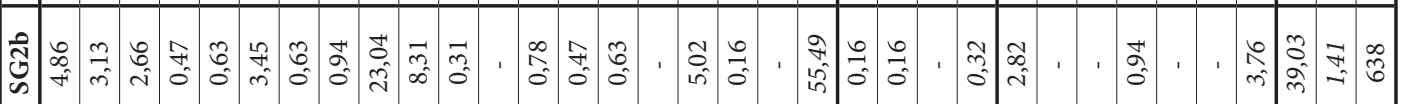

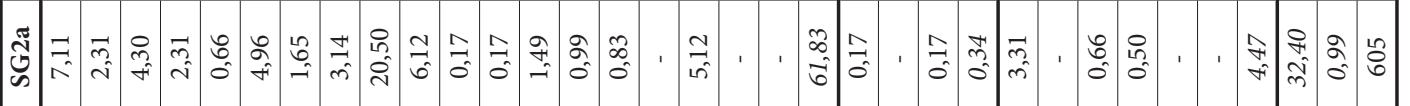

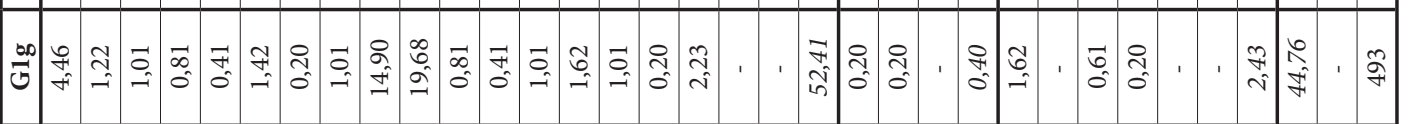

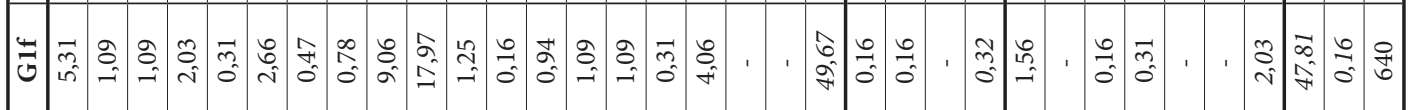

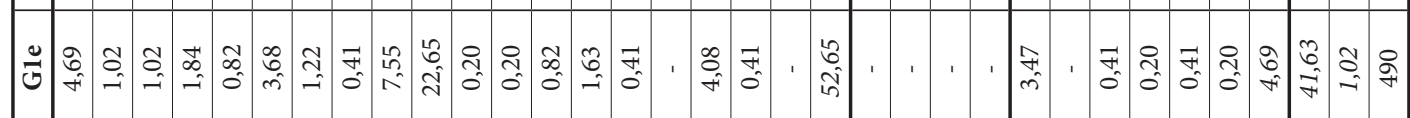

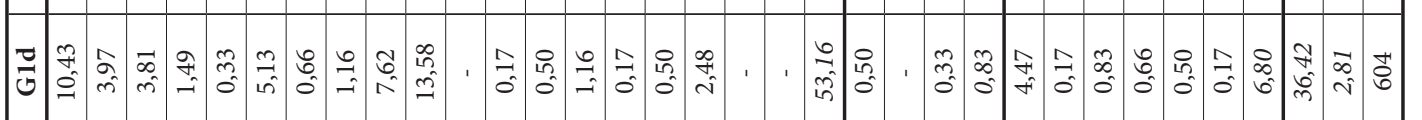

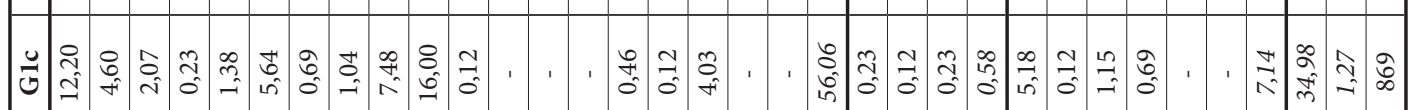

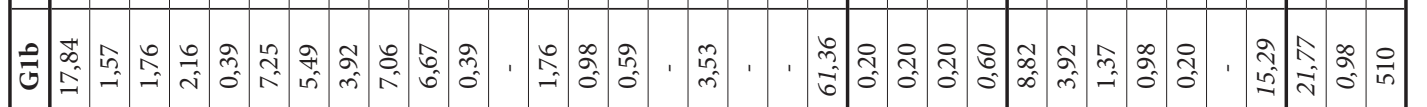

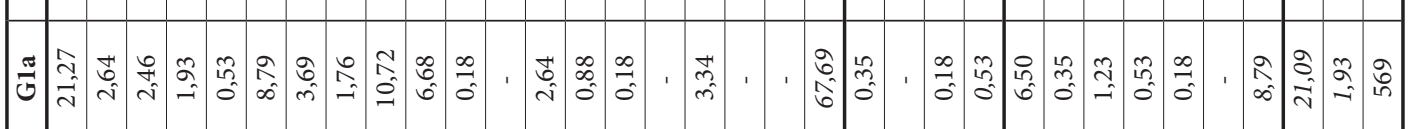

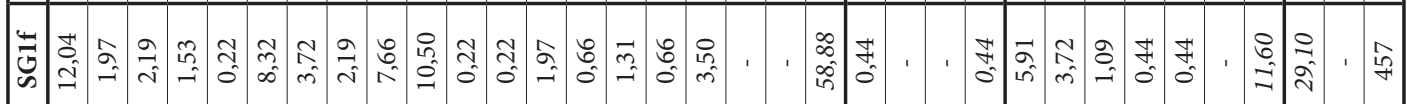

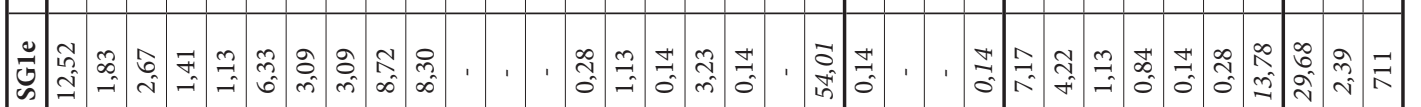

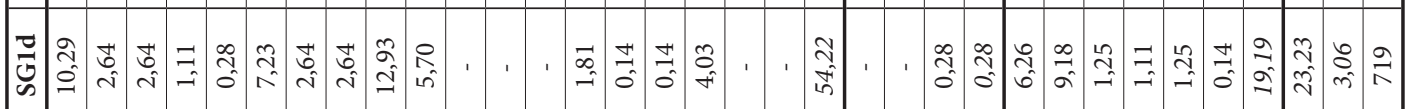

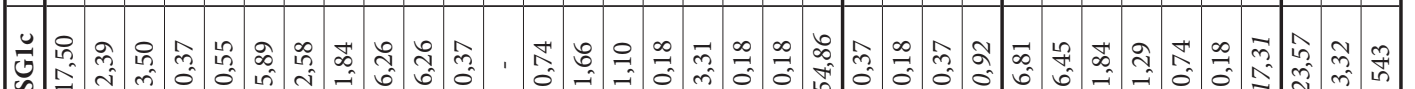

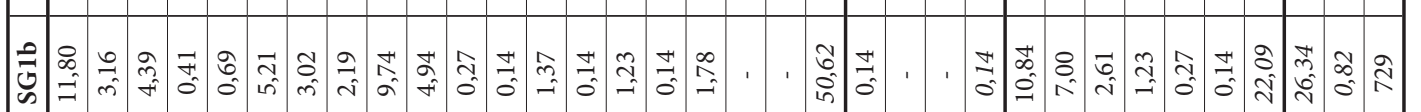

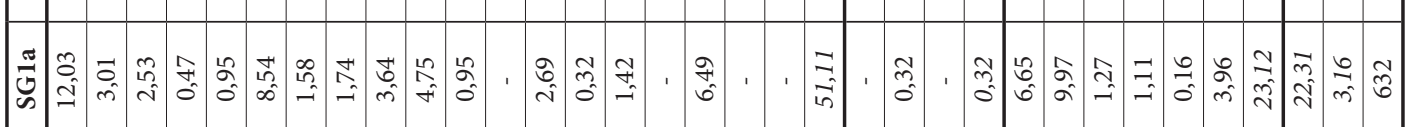

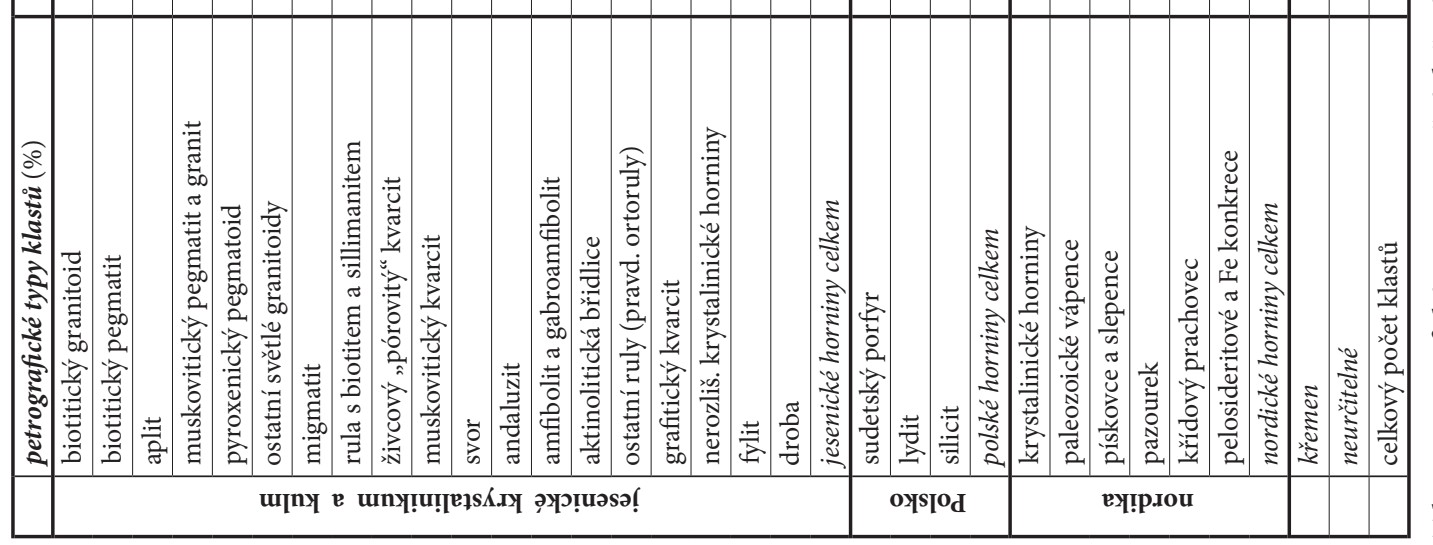


na litofaciích. Podle těchto znaků pochází převážná většina křemene $\mathrm{z}$ jesenických metamorfitů a žilných granitoidů a je tedy místního původu (Gába 1974).

Mezi světlými granitoidy dominují horniny žulovského plutonu (biotitický drobno-střednozrnný granitoid, biotitický pegmatit a aplit). Některé klasty zachycují vzájemné kontakty mezi těmito horninami. Migmatit, jehož klasty tvoří hlavně leukosom s biotitovými pásky a dále pyroxenický pegmatoid mají výchozy po obvodu žulovského plutonu. Muskovitický granit a pegmatit primárně pocházejí z pásma drobných těles těchto hornin mezi Jeseníkem a Mikulovicemi, čemuž nasvědčují jejich znaky (masivní i usměrněná textura, vysoký podíl muskovitu, minimum nebo absence biotitu, mnohdy červená zrna granátu velká $0,5-2,0 \mathrm{~mm}$, častá grafická struktura). Kategorie ostatních světlých granitoidů zahrnuje různé typy, včetně usměrněných a leukokratních, pocházejících hlavně z periferních zón žulovského plutonu, kde se granitoidy vyznačují značnou variabilitou. Muskovitický kvarcit je většinou identický s drakovským kvarcitem, budujícím hlavně sz. část Zlatohorské vrchoviny. Provenienčně s ním budou souviset klasty svorů, fylitu a andaluzitu. Živcový kvarcit odpovídá zejména tzv. „pórovitému“ kvarcitu Gáby - Peka (1999), pocházejícímu ze Sokolského hřbetu. Rula s biotitem a sillimanitem se shoduje s pararulou budující velkou část údolí Bělé, včetně bezprostředního podloží a okolí lokality. Amfibolit pochází z jesenického amfibolitového masivu. Vzhledem k jeho významné úloze na geologické stavbě studovaného území je jeho zastoupení nápadně nízké ( 0,0-3,5\%). Aktinolitická břidlice má původ bud' také $\mathrm{v}$ jesenickém amfibolitovém masivu nebo ve vrbenské skupině (Zlatohorské vrchovině). Mezi ostatními rulami se pravidelně objevují bělošedé jemnozrnné ruly s bitotitem nebo muskovitem na foliačních plochách. Pravděpodobně se jedná o gieraltowskou ortorulu z Rychlebských hor, odkud pochází i grafitický kvarcit, který je typickou složkou ledovcových uloženin Jesenicka (Gába - Pek 1999). Některé horniny patří podle svého vzhledu nejspíš k jesenickému krystaliniku, ale bliže je nelze určit. Velmi vzácnou komponentou je kulmská droba.

Nordické klasty jsou petrograficky nejpestřejší na bázi litofaciální asociace SG1, kde mají maximální zastoupení. Kromě krystalinických hornin (granitů, ortorul, porfyrů a kvarcitů), pískovců, slepenců a pazourků (včetně bílé kůry pazourků) se zde velmi hojně vyskytují vápence $s$ faunou ordovického a silurského stárí. Podřadně jsou zastoupeny šedé a zelenošedé bioturbované prachovce s glaukonitem, muskovitem a faunou křídového stáríi. Podíly vápenců a křídových prachovců se do nadloží snižují a od facií GCm ve svrchní části asociace G1 zcela mizí. Proměnlivě jsou zastoupeny pelosideritové a železité konkrece. Polské horniny představují jen podřadnou prríměs, mezi provenienčně neurčitelnými klasty se řídce vyskytuje bazalt.

\section{Interpretace a diskuze Vývoj depozičního prostředí kolnovických glacifluviálních sedimentů}

Nahoru hrubnoucí sekvence jsou z pleistocenních proglaciálních výplavových plošin běžně popisovány (Costello - Walker 1972, Zieliński - Van Loon 2003, Salamon 2008) a samotný charakter těchto sekvencí potvrzuje interpretaci depozičních prostředí jako divočících plošin (Zieliński - Van Loon 2003). Sled litofaciálních asociací SF-G1 představuje plynulou nahoru hrubnoucí sekvenci. Asociace SG2 a G2 už tento trend nevykazují tak zřetelně.

Asociace SF reprezentuje sedimenty mělkých širokých vedlejších koryt $s$ velmi slabým prouděním a odpovídá ve vztahu k ledovci nejdistálnějším částem divočících glacifluviálních systémů (model 11 Mialla 1985, litofacie D5 Zielińského - Van Loona 2003).

Asociace $S$ se zpočátku tvořila $\mathrm{v}$ korytech zahloubených do podložních písků (Se), výše se jedná o ploché příčné lavice (transverzální bary, Sp), akretující uvnitř širokých koryt v poproudovém směru (Platte-type macroforms Crowleyho 1983, model 9 Mialla 1985, litofacie D3 Zielińského - Van Loona 2003). Jelikož byly písky facie Sp zastiženy i v podloží litofaciální asociace SF, je možné, že asociace SF představuje součást asociace $S$, kdy se čeřinově zvrstvené písky vyvíjely na povrchu příčných lavic během opadání povodně na divočící plošině. Přitom se v mělkých širokých depresích vedlejších koryt ukládal prach.

Asociace SG1 odráží zvýšení rychlosti proudění na výplavové plošině $\mathrm{v}$ souvislosti s povodňovými stavy. Bazální členy vznikly zahloubením koryt do starších uloženin a jejich následným vyplněním sedimenty s různými podíly písku a štěrku (SGe, GSe). Jedná se o litofacie D1 a P3 Zielińského - Van Loona (2003) vzniklé během přívalových povodní, spojených se zvýšenou ablací ledovce. Po vyplnění hlubokých koryt migrovaly v mladších mělčích korytech široké prríčné, poproudově akretující lavice (SGp, GSp, Sp). Mezi nimi se ve vedlejších kanálech ukládaly korytovitě zvrstvené sedimenty (SGt, St). Střídání štěrkovitopískových až písčitoštěrkových setů s pískovými ukazuje na rychlé migrace menších koryt s rozdílnou rychlostí proudění. Rozsáhlá akumulace složená z mnoha setů litofacie St, mocných max. $0,5 \mathrm{~m}, \mathrm{v}$ jv. části odkryvu dokládá stálou agradaci sedimentů v malých vedlejších korytech na výplavové plošině, v laterálním sousedství větších koryt vyplňovaných mocnějšími a širšími lavicemi. Záznamem náhlých povodní jsou tenké polohy hrubých štěrků. Při sedimentaci nejvyšší části asociace docházelo na plošině ke změlčování a zmenšování koryt, což ukazuje na přechod do okrajových částí výplavové plošiny. Asociace SG1 jako celek odpovídá modelu 10 Mialla (1985) a distálním faciím D1-D3 Zielińského - Van Loona (2003). Vzhledem k relativní hrubozrnnosti sedimentů, zejména na bázi, lze uvažovat o přechodné zóně mezi proximálním a distálním vývojem divočící plošiny. Ve v. části pískovny se její bazální členy zařezávají do asociace $\mathrm{S}$, ale ve střední části odkryvu přímo do asociace SF, protože písková asociace postupně vykliňuje. Asociace SF, S a SG1 spolu proto souvisejí i prostorově a představují 
postupnou migraci koryt s rychlejším prouděním do této části plošiny. Hojné prachové závalky představují intraklasty erodovaných sedimentů opuštěných koryt nebo ledovcových jezer. Závalky diamiktonů vznikly erozí tillů. Sedimenty asociace SG1 tedy vznikaly $\mathrm{z}$ podstatné části rozplavením dominantně jemnozrnných uloženin a proto obsahují jen příměs velkých klastů, byt' síla proudění byla dostatečná k jejich transportu.

Asociace G1 zaznamenává migraci hlavních koryt na tuto část výplavové plošiny. Do uložených sedimentů předchozí asociace se zahloubila až 15 m široká koryta, vzápětí vyplněná zvrstvenými štěrky (GSe). Následně se v korytech s vysokou energií proudění ukládaly podélné lavice masivních štěrků (longitudinální bary) a při opadávání povodní uloženiny litofacie GSp (transverzální bary). Mocná tabulární akumulace litofacie GCm představuje amalgamované podélné lavice, migrující v kanálech výplavové plošiny během maximálních povodní za vrcholící ablace ledovce. Odpovídající sedimenty se ukládají za nejvyšších povodní v proximálních zónách proglaciálních toků horských ledovců (např. Boothroyd - Ashley 1975). Spodní část asociace G1 se zahloubenými koryty odpovídá litofacii P3, střední a svrchní část potom litofacii P2 Zielińského - Van Loona (2003) a modelu 2 Mialla (1985), tedy proximálním zónám divočících glacifluviálních systémů.

Asociace SG2 vznikala za podobných podmínek jako SG1, ale je celkově hrubozrnnější, proto nepozorujeme tak pestré litofaciální přechody. Dominantním prvkem byly široké příčné lavice migrující v korytech. Jedná se tedy o hrubozrnnější ekvivalent k modelu 10 Mialla (1985) a litofaciím D1-D3 Zielińského - Van Loona (2003). Asociace G2 je ekvivalentní k asociaci G1, pouze velikost koryt a tím i sedimentárních těles byla menší.

Nahoru hrubnoucí sekvence SF-G1 může být výsledkem dvou procesů. První možností je přesun stále proximálnějších litofaciálních asociací v čase do jednoho místa výplavové plošiny. Druhou možností je zákonitá změna říčního stylu prrímo na místě, v souvislosti s narůstající mírou ledovcové ablace a tím i intenzitou povodní. Sekvence SG2-G2 pak zaznamenává další podobný cyklus, ovšem nevýrazně vyvinutý. Tento trend popisuje Salamon (2008) z předhưří Gór Opawských (severní část Nízkého Jeseníku) a vysvětluje jej sezónní proměnlivostí tání a tím i vodnatos- ti toků na plošině. Jelikož v Kolnovicích akretovala většina sedimentárních těles generelně ve směru $\mathrm{Z}-\mathrm{V}$, mohly se rovněž zdejší glacifluviální uloženiny vyvíjet na divočící plošině, sledující okraj kontinentálního ledovce (obr. 3), jak to ve svém modelu předpokládá Salamon (2008).

Podle složení štěrků můžeme zkoumané sedimenty rozdělit do tří sérií. První série odpovídá asociaci SG1 a vyznačuje se vysokými podíly nordik na bázi a jejich mírným ubýváním do nadloží. Významnou roli tedy hrál př́nos materiálu z vnitřní části ledovce, na kterou jsou výskyty provenienčně cizorodých hornin vázány (Boulton 1978, Nývlt - Hoare 2000). Druhá série je identická se spodní částí asociace G1 mezi 12. a 14. m mocnosti, která se vyznačuje širokou proměnlivostí podílů provenienčních i petrografických skupin klastů. Materiál pro tyto štěrky 
zčásti pochází z erodovaných sedimentů podložní asociace (zahloubená koryta facie GSe), částečně z přínosu nových klastů, tentokrát hlavně místních hornin $\mathrm{z}$ jesenického krystalinika. Svrchní část asociace G1 (mocné těleso GCm) a sled asociací SG2 a G2 tvoří třetí sérii, charakteristickou vysokými podíly křemene a jesenických hornin. Při ukládání těchto sedimentů byla plošina dotována především materiálem místního původu, pravděpodobně $\mathrm{z}$ báze a od čela ledovce. V litofaciích GCm uvnitř asociace G1 roste podíl křemene a místních kvarcitů také kvůli odolnosti těchto složek vůči vysokoenergetickému trakčnímu transportu. Celkový trend poklesu podílu nordik a nárůstu podílu místních jesenických hornin a křemene do nadloží lze vysvětlit postupným odtáváním ledovce od povrchu $\mathrm{k}$ bázi, kdy nejdříve dominoval přísun materiálu $\mathrm{z}$ vnitřku a teprve poté od báze ledovce. Tento faktor se kombinoval $\mathrm{s}$ dotováním plošiny prrítoky $\mathrm{z}$ různých míst široké čelní zóny ledovce, $\mathrm{z}$ nichž mohl být přinášen materiál s různými podíly provenienčních skupin (obr. 3).

\section{Rozdíly mezi glacifluviální plošinou a terminoglaciálními kužely}

Chaotická litofaciální proměnlivost bez zřetelných proximálně-distálních trendů ve změnách zrnitosti a litofacií, pozorovatelných na krátkou vzdálenost, společně s významnou rolí velkých těles šikmo zvrstvených štěrků a mocných souborů korytovitě zvrstvených písků jsou důležitými znaky, jimiž se divočící výplavové plošiny odlišují od terminoglaciálních kuželů (Krzyszkowski - Zieliński 2002, Zieliński - Van Loon 2003). Na základě litofaciální analýzy můžeme tedy kolnovické glacifluviální sedimenty považovat za uloženiny divočící výplavové plošiny proglaciální zóny. Během deglaciace se mezi Sokolským hřbetem na Z a Zlatohorskou vrchovinou a Górami Opawskými na $V$ rozšiřovala před ustupujícím ledovcem široká plošina. Po jejím povrchu proudily glacifluviální divočící řeky, vytékající z ledovcového štítu na různých místech jeho dlouhého čela (obr. 3). Generelní směr odtoku byl k V, nejspíš do deprese Bělé a odtud pod ledovcový štít.

Nedaleko od studované lokality leží dvě další glacifluviální akumulace, uložené před čelem ledovce během jeho stagnace a ústupu, které se však od Kolnovic především petrograficky značně liší. První se nachází na z. okraji Zlatohorské vrchoviny, v bočním svahu údolí řičky Javorné. Jedná se o malý terminoglaciální kužel, který byl vytvořen glacifluviálními toky proudícími z úzkého výběžku ledovce, který spočíval v sedle mezi dvěma vrcholy nad údolím Javorné (Hanáček 2011), viz obr. 3. Druhou lokalitou je až 45 m mocná, ale lokálně omezená akumulace převážně glacifluviálních uloženin (méně glacilakustrinních sedimentů na periferii a resedimentovaných tillů ve svrchní části) v severním svahu údolí Bělé v Písečné (Gába 1981, Prosová 1981, Cháb et al. 2004). Podle pozice, mocnosti a laterální omezenosti akumulace lze i tuto lokalitu považovat za terminoglaciální kužel (Cháb et al. 2004) nebo soustavu několika kuželů (Prosová 1981), viz obr. 3. Jelikož na obou lokalitách naprosto převažovala glacifluviální sedimentace, lze oba kužely označit podle klasifikace Krzyszkowského - Zielińského (2002) jako typ kuželu vzniklých sedimentací převážně ve vodním prostředí (waterlaid deposits-dominated ice-marginal fan, typ C). V Písečné se projevoval proximálně-distální trend od hrubozrnných glacifluviálních štěrků po prachovité glacilakustrinní sedimenty na periferii tělesa (Gába 1981, Prosová 1981), což je typický znak vějírové sedimentace (Krzyszkowski - Zieliński 2002, Zieliński - Van Loon 2003). Depoziční prostředí obou lokalit bylo velmi podobné, byt kužely vznikly v odlišných glaciálech (Javorná - starší elsterský glaciál, Písečná - mladší elsterský glaciál, Cháb et al. 2004).

Akumulace obou kuželů se vyznačují petrograficky monotónním materiálem. V Písečné tvoří 40-50\% klastů živcový kvarcit pocházející z přilehlých výchozů v Sokolském hřbetu, resp. z koluvií na jeho sv. úpatí. Podíly nordik a polských hornin jsou velmi nízké a v rámci glacifluviálu do nadloží rostou $\mathrm{z} \sim 2$ na $\sim 4 \%$ (Gába 1981). U Javorné je štěrkový materiál tvořen $\mathrm{z} \sim 65 \%$ také horninami $\mathrm{z}$ přilehlých vrcholků, resp. koluvií na jejich svazích (drakovský kvarcit a doprovodné horniny). Nordika jsou podřadná i když jejich zastoupení je kolísavější ( 2,5-8 \%). Oproti tomu v Kolnovicích žádná z petrografických skupin zřetelně nepřevládá, pouze s výjimkou litofacií GCm v asociaci G1 (dominance křemene a kvarcitů). Podíly nordik klesají od báze do nadloží v rámci sekvence asociací SF-G1 $\mathrm{z} \sim 23 \%$ na $\sim 2 \%, \mathrm{v}$ nadložní sekvenci asociací SG2-G2 mírně stoupají z $\sim 4,5$ na $\sim 7 \%$.

Rozdíly ve složení materiálu mezi terminoglaciálními kužely a výplavovou plošinou odrážejí variabilitu zdrojů materiálu v rámci ledovce. U kuželů proudily glacifluviální toky z jednoho výběžku ledovce, tzn. z omezené části ledovcového štítu, proto složení materiálu odpovídá jedné konkrétní části ledovce, př́padně podloží pod touto částí ledovce. Tyto okrajové výběžky byly hlavně na bázi a čele značně nabohaceny o materiál $\mathrm{z}$ bezprostředního podloží a nejbližšího okolí (Gába 1981, Hanáček 2011). $\mathrm{Na}$ výplavové plošině proudilo více toků ze vzájemně vzdálenějších míst dlouhého čela ledovcového štítu, které přinášely materiál s různými poměry provenienčních a petrografických skupin (viz obr. 3). Uvedené rozdíly byly podmíněny geomorfologicky. Terminoglaciální kužely vznikaly na linii maximálního rozsahu zalednění. Progradovaly $z$ úzkých výběžků ledovce situovaných nad bočními stranami říčních údolí, kde terén upadal směrem od ledovcového čela. $Z$ tohoto důvodu odpovídá materiál terminoglaciálních kuželů složení detritu transportovaného pouze v konkrétním ledovcovém výběžku, resp. horninové náplni přímého podloží a bezprostředního okolí omezené části ledovce. Výplavová plošina se mohla vyvíjet až v pokročilejší fázi deglaciace, kdy ledovec ustoupil $\mathrm{z}$ bezprostředního podhůří dále $\mathrm{k} \mathrm{S}$ a mezi pohořím a širokou frontou ledovcového štítu se otevřel relativně plochý sedimentační prostor. Z vưči sobě vzdálených částí ledovcového čela pak glacifluviální toky transportovaly na plošinu různorodý materiál. Z této př́íčiny je vertikální variabilita podílů klastů různého původu u sedimentů výplavových plošin mnohem větší než v případě sedimentů terminoglaciálních kuželů. 


\section{Závěry}

Podle litofaciální analýzy představují glacifluviální sedimenty $\mathrm{v}$ kolnovické pískovně tělesa př́ičných a podélných lavic, vyvíjejících se $\mathrm{v}$ širších korytech, a dále sedimenty zahloubených koryt. Generelní směr proudění byl zhruba k východu. Štěrky jsou materiálově a provenienčně pestré, priičemž žádná z petrografických skupin zřetelně nepřevládá. Výjimkou jsou pouze nejhrubší masivní štěrky, ve kterých dominují křemen a kvarcity. Podle těchto znaků lze studované sedimenty interpretovat jako uloženiny divočící výplavové plošiny, probíhající podél čela ledovce. To bylo orientováno hlavně ve směru $Z-V$, samozřejmě s místními odchylkami. Ve vrstevním sledu byly rozlišeny dvě nahoru hrubnoucí sekvence, odrážející bud' laterální migraci hlavních a vedlejších koryt po výplavové plošině nebo vývoj říčního režimu v čase na jednom místě. Tyto změny souvisely s klesající nebo stoupající intenzitou ablace ledovcového štítu. Během ukládání sedimentů spodního nahoru hrubnoucího cyklu převládal nejdříve př́nos materiálu $\mathrm{z}$ vnitřních částí ledovce a teprve poté od báze a čela ledovce, což dokládá postupný pokles podílu nordických klastů. Př́ččnou je převaha povrchového odtávání a ztenčování ledovcového štítu nad ústupem jeho čela.

Polymiktnost štěrkového materiálu, proměnlivé množství různých typů klastů a variabilita jesenických hornin jsou důležitými petrografickými indikátory, které v ob- lasti mezi Sokolským hřbetem a Zlatohorskou vrchovinou odlišují uloženiny terminoglaciálních kuželů od sedimentů výplavových plošin. Rozdíly souvisejí s geomorfologickou pozicí obou depozičních prostředí. Terminoglaciální kužely vznikaly na periferii ledovcového štítu, kde z výběžků ledovce nad bočními svahy říčních údolí progradovaly sedimenty směrem od čela ledovce do těchto údolí. Kužely tedy byly ovlivněny pouze lokálními podmínkami, což se odráží v jejich monotónním materiálovém složení. Terminoglaciální kužely představují ve studované oblasti sedimenty z počáteční fáze ústupu ledovce. Výplavová plošina se naopak mohla vyvíjet až $\mathrm{v}$ pokročilejší fázi deglaciace, kdy se před čelem ledovcového štítu vytvořil dostatečný plochý prostor pro migraci soustav divočících tokủ. Ty proudily podél okraje štítu a přinášely materiál z různých částí ledovce. Proto jsou klastika výplavové plošiny mnohem pestřejší.

\section{Poděkování}

Určování fosiliferních klastů proběhlo v rámci interního grantu Slezského zemského muzea (IGS201102 Paleontologický výzkum sedimentárních nordických souvkü Slezska a severní Moravy). Za cenné připomínky děkuji Danielu Nývltovi, Slavomíru Nehybovi, Jaroslavu Kadlecovi a Tomaszi Zielińskému. Za korekturu textu jsem zavázán Haně Uhliřové. 


\section{Literatura}

Boothroyd, J. C. - Ashley, G. M. (1975): Processes, bar morphology, and sedimentary structures on braided outwash fans, northeastern Gulf of Alaska. - In: Jopling, A. V. - McDonald, B. C. (eds): Glaciofluvial and Glaciolacustrine Sedimentation, SEPM Special Publication, 23, 193-222.

Boulton, G. S. (1978): Boulder shapes and grain-size distributions of debris as indicators of transport paths through a glacier and till genesis. - Sedimentology, 25, 773-799.

Costello, W. R. - Walker, R. G. (1972): Pleistocene sedimentology, Credit River, Southern Ontario: a new component of the braided river model. - Journal of Sedimentary Petrology, 42, 2, 389-400.

Crowley, K. D. (1983): Large-scale bed configurations (macroforms), Platte River Basin, Colorado and Nebraska: Primary structures and formative processes. - Geological Society of America Bulletin, 94, 117-133.

Gába, Z. (1974): Valounové analýzy ledovcových uloženin na Jesenicku. - Časopis Slezského Muzea Opava (A), 23, 49-56.

Gába, Z. (1981): Uloženiny kontinentálního ledovce u Písečné na severní Moravě. - Časopis Slezského Muzea Opava (A), 30, 3 , 241-253.

Gába, Z. - Pek, I. (1999): Ledovcové souvky moravskoslezské oblasti. - Okresní vlastivědné muzeum v Šumperku.

Hanáček, M. (2011): Sedimenty terminoglaciálního kuželu v údolí Javorné na Zlatohorsku. - Acta Musei Moraviae, Scientiae geologicae, 96, 1, 61-86.

Cháb, J. - Čurda, J. - Kočandrle, J. - Manová, M. - Nývlt, D. - Pecina, V. - Skácelová, D. - Večeřa, J. - Žáček, V. (2004): Základní geologická mapa České republiky $1: 25$ 000, list 14-224 Jeseník s Vysvětlivkami. - Česká geologická služba.

Krzyszkowski, D. - Zieliński, T. (2002): The Pleistocene end moraine fans: controls on their sedimentation and location. - Sedimentary Geology, 149, 73-92.

Miall, A. D. (1985): Architectural-Element Analysis: A New Method of Facies Analysis Applied to Fluvial Deposits. - EarthScience Reviews, 22, 261-308.

Nývlt, D. - Engel, Z. - Tyráček, J. (2011): Pleistocene glaciations of Czechia. - In: Ehlers, J. - Gibbard, P. L. - Hughes, P. D. (eds): Quaternary Glaciations - Extent and Chronology Part IV - a closer look, Developments in Quaternary Science, Elsevier, $37-46$.

Nývlt, D. - Hoare, P. G. (2000): Valounové analýzy glacifluviálních sedimentů severních Čech. - Bulletin Czech Geological Survey, 75, 2, 121-126.

Pouba, Z. - Dvořák, J. - Kužvart, M. - Mísař, Z. - Musilová, L. - Prosová, M., Röhich, P. - Skácel, J. - Unzeitig, M. (1962): Vysvětlivky k přehledné geologické mapě ČSSR $1: 200$ 000, list M-33-XVIII Jeseník. - Ústř̌ední ústav geologický.

Prosová, M. (1981): Oscilační zóna kontinentálního ledovce. Jesenická oblast. - Acta Universitatis Carolinae, Geologica, 3, $265-294$.

Salamon, T. (2008): Origin of Pleistocene outwash plains in various topographic settings, southern Poland. - Boreas, 38, 362-378.

Sikorová, J. - Víšek, J. - Nývlt, D. (2006): Texture and petrography of glacial deposits in the northern foothill of the Hrubý Jeseník and Rychlebské Mts., Czechia. - Geological Quarterly, 50, 3, 345-352.

Svoboda, J. - Chaloupský, J - Bernard, J. - Dornič, J. - Kalášek, J. - Klein, V. - Malkovský, M. - Mísař, Z. - Pacovská, E. - Pauk, F. - Rezáč, B. - Skácel, J. - Soukup, J. - Tásler, R. - Vodička, J. - Zrůstek, V. (1961): Vysvětlivky k přehledné geologické mapě ČSSR 1 : 200 000, list M-33-XVII Náchod. - Ústřední ústav geologický.

Zieliński, T. - Van Loon, A. J. (2003): Pleistocene sandur deposits represent braidplains, not alluvial fans. - Boreas, 32, 590-611. Žáček, V. (1995): Geologická mapa ČR 1 : 50 000, list 14-22 Jeseník. - Český geologický ústav.

Žáček, V. - Čurda, J. - Kočandrle, J. - Nekovař́́k, Č. - Nývlt, D. - Pecina, V. - Skácelová, D. - Skácelová, Z. - Večeřa, J. (2004): Základní geologická mapa České republiky 1:25 000, list 14-222 Vidnava s Vysvětlivkami. - Česká geologická služba. 